\title{
Tri Hita Karana Oriented Problem Based Learning Improves Natural Science Learning Outcomes
}

\author{
Anak Agung Permatasari ${ }^{1}$, I Wayan Widiana ${ }^{2}$, Alexander Hamonangan ${ }^{3}$ \\ ${ }^{12}$ Primary School Teacher Education Study Program, FIP, Undiksha, Indonesia \\ ${ }^{3}$ Educational Psychology Study Program and Guidance, FIP, Undiksha, Indonesia.
}

\section{A R T I C L E I N F O Article history: \\ Received 18 March 2020 \\ Received in revised form 30 April 2020 \\ Accepted 5 May 2020 \\ Available online 15 May 2020}

Kata Kunci:

Tri Hita Karana, PBL

Keywords:

Tri Hita Karana, PBL

Based Learning berorientasi $\mathrm{Tr}$ sebab itu, model pembelajaran Problem Based Learning berorientasi Tri Hita Karana cocok diterapkan untuk mengatasi hasil belajar IPA yang rendah.

\begin{abstract}
A B S T R A K
Penelitian ini berfokus pada rendahnya hasil belajar IPA siswa kelas V. Tujuan penelitian ini adalah untuk menganalis pengaruh model PBL berorientasi Tri Hita Karana terhadap hasil belajar IPA siswa kelas V. Sampel dalam penelitian ini berjumlah 56 siswa. Dalam penelitian ini data dikumpulkan dengan teknik tes menggunakan instrumen tes objektif bentuk pilihan ganda yang sebelumnya sudah dianalisis kualitas kelayakannya dengan uji validitas, reabilitas, daya pembeda, dan tingkat kesukaran. Data yang telah diperoleh kemudian dianalisis menggunakan uji-t. Berdasarkan hasil analisis uji-t diperoleh T-count $=5,42$ sedangkan nilai T-table pada taraf signifikan 5\% dengan derajat kebebasan 28 $+28-2=54$ adalah 1,67. Berdasarkan T-count $=5,42>\mathrm{T}$-table $=1,67$ maka $\mathrm{H}_{0}$ ditolak. Hasil analisis tersebut membuktikan bahwa terdapat perbedaan yang signifikan antara kelompok siswa yang dibelajarkan dengan model Problem Based Learning berorientasi Tri Hita Karana dengan kelompok siswa yang dibelajarkan dengan model pembelajaran konvensional. Dari hasil analisis uji-t dan rata-rata hasil belajar tersebut dapat disimpulkan bahwa model Problem Hita Karana berpengaruh positif terhadap hasil belajar IPA siswa kelas V. Oleh
\end{abstract}

\section{A B S T R A C T}

This research focused on the low learning outcomes of Natural Science students in class V.. The purpose of this study was to analyze the effect of the Tri Hita Karana oriented PBL model on the learning outcomes of the fifth grade Natural Science students. The sample in this study amounted to 56 students. In this study, data were collected using a test technique using an objective test instrument with multiple choice forms which had previously been analyzed for the quality of eligibility by testing the validity, reliability, distinguishing features, and level of difficulty. The data that has been obtained is then analyzed using t-test. Based on the results of the t-test analysis, $\mathrm{T}$-count $=5.42$, while the value of $\mathrm{T}$-table at a significant level of $5 \%$ with degrees of freedom $28+28-2$ $=54$ is 1.67 . Based on $\mathrm{T}$-count $=5.42>\mathrm{T}$-table $=1.67$ then $\mathrm{H}_{0}$ is rejected. The results of the analysis prove that there are significant differences between the groups of students who are taught with the Tri Hita Karana oriented Problem Based Learning model with groups of students who are taught with conventional learning models. From the results of the t-test analysis and the average learning outcomes it can be concluded that The Tri Hita Karana oriented Problem Based Learning model has a positive effect on the Natural Science learning outcomes of Class V students. Therefore, the Tri Hita Karana oriented Problem Based Learning model is suitabel for dealing with low Natural Science learning outcomes

\section{Introduction}

Natural Science is an obligatory course in Indonesian curriculum. Natural Science teaches the students on understanding natural phenomena in their environment. According to Sulthon (2016) Natural Science is a study that is acquired from the approach of real things which is done continually, systematically, and objectively. Natural Science is close to environment so that its learning becomes an obligatory which is able to make the students interact with the environment when the learning process happens (Ardaya, 2016). According to UUSPN (in Muakhirin, 2014) the Natural Science purpose is to develop knowledge, understanding, and analytical ability of the students towards the environment. By reaching the goal of Natural Science learning, the students will be able to solve their problems regarding to the environmental nature and every day's problems. Based on Trianto (in Wayan Weda Gustana Putra et al., 2016) good interaction shows that the purpose of a learning is reached. Drawing a 
line, in reaching the succeeded goal of Natural Science learning, interaction is needed when the learning process happens. The interaction within Natural Science learning will determine the success of the students in exploring and constructing their knowledge. According to Putra (2020), in the community environment as a source of student learning there are guidelines for conducting good interactions, if the guidelines are applied in learning then the interaction in learning will run better and in accordance with the needs of the local community environment. Therefore, it is important for educators to be able to carry out learning in accordance with the character of students and the demands of the community environment that are considered good applied in learning.

According to Soviawati (2011) elementary school students have the character can not think abstractly so they need a learning that can provide a real picture or direct experience for them to understand. Besides elementary school age children also like physical activity so they will be eager to learn to understand the material if the learning process can accommodate physical activity for exploration and creativity. This is in line with Silberman's opinion (in Sohibun, 2014) which states that when students learn by listening, seeing, discussing, spelling and teaching, students will better understand what they are learning so that it will have a good impact on their learning outcomes.

Based on the results of observations made in Cluster III Selemadeg District on October 28, 2019 the implementation of Natural Science learning in primary schools currently does not fully pay attention to the characteristics of students who have not been able to think abstractly and like physical activity. The learning model used by teachers when learning Natural Science is a learning model that is too teacher-centered that does not direct students to find knowledge by exploring directly with the environment such as using lecture methods, one-way questions and answers, and assignments. Through interviews with principals in Selemadeg Elementary School III, the reason why teachers do not use innovative learning models is the lack of insight and skills of teachers in varying learning models that make students actively explore. Most students during the learning process seem unfocused and when interviewing about the material that has been given during learning students look confused explaining the material that has been explained by the teacher during learning. Judging from the Middle Semester Deuteronomy (UTS) data it can be seen that the percentage of students who surpassed KKM is only 45\%. If the percentage is consulted with the Benchmark Reference Assessment (PAP) according to Agung (2010) the percentage of students who exceed the KKM is in the very low category. This is consistent with the results of the 2019 Program for International Student Assessment (PISA) research published in Jawa Pos that Indonesian students' learning outcomes fell from 403 points to 396 points so that the PISA ranking dropped from 72nd to 77th which means overall in Indonesia the Natural Science or Natural Science learning outcomes of students are indeed very low. If the problem is not immediately addressed, it will certainly hamper the progress of human resources in Indonesia in terms of Natural Science and technology.

So far, a lot of research has focused on improving Natural Science learning outcomes. Some of them are research conducted by Ariadi (2014) which shows that the class applied by the Group Investigation learning model has a positive effect on the learning outcomes of Grade IV Natural Science students. The research conducted by Ardiansyah (2017) resulted in the conclusion that the Problem Solving model influenced the increase in Natural Science learning outcomes of fifth grade students. The study conducted by Fauziyah (2017) concluded that the Probing-Promting model had a significant effect on the learning outcomes of Class V students conducted by Mahpudin (2018) which shows that the experimental method can improve the learning outcomes of Class V Natural Science students. Research conducted by Widura (2018) states that the CORE learning model influences the learning outcomes of Class IV students' Natural Science learning. Research conducted by Amir \& Haling (2018) which concluded that the scientific approach affects the learning outcomes of Natural Science students in elementary schools. Research conducted by Priani (2018) which shows a Problem Based Learning model assisted by image media has a positive effect on the learning outcomes of Natural Science.

Based on the research that has been done in improving the science learning outcomes can be done by applying a model that can increase the active role of students when learning to explore and construct knowledge. Therefore, with consideration of previous research, a solution that can be offered to overcome the low learning outcomes of science is to apply the Problem Based Learning model, this learning model is the same as previous research that directs the active role of students in learning. Fathurrohman (2015) states that Problem Based Learning can involve students actively solving problems with the stages of the scientific method so that students can learn knowledge related to the problems raised at the same time have problem solving skills, in addition Nurqomariah (2015) believes that the Problem Based Learning model is able to encourage students to develop their knowledge by playing an active role when learning. The Problem Based Learning Model is based on Jerome S. Bruner's learning theory which states that the knowledge obtained by students 
independently by direct exploration will be more meaningful to students (Rusman, 2012). This shows that the Problem Based Learning model is compatible with science learning which requires students to learn knowledge through investigations. The strength of the Problem Based Learning model compared to other learning models lies in the application of scientific methods and scientific attitudes in learning that make learning more conducive. This learning model can also adjust to the character of elementary school age children who love physical activity and cannot think abstractly.

The implementation of innovative learning models that direct the active role of students when learning will not run optimally if the interaction in learning is not directed properly. In creating a good interaction during learning can be done by inserting the teachings of the concept of local Balinese wisdom, Tri Hita Karana. According to Afif (in Suci, 2018) Tri Hita Karana is a guide for Balinese people in making a harmonious relationship. In learning there is always a relationship or interaction between students and teachers or students and students so it is necessary to build a harmonious relationship for a conducive learning atmosphere. The implementation of Tri Hita Karana in learning will direct the character of students to be better during the learning process, it is in accordance with the opinion of Dikta (2020) which states Tri Hita Karana is a local wisdom that is recognized by UNESCO as a tool to develop education through the improvement of character that can be done globaly. Mandra \& Dhammananda (2020) also believes that the implementation of Tri Hita Karana in learning can encourage students to achieve an achievement. That is because the concept of Tri Hita Karana which includes Parahyangan or harmonious interaction with God will lead students to obey religious teachings in learning so as to minimize bad character, Pawongan or harmonious interaction between humans and humans will lead students to collaborate or work together with their friends when exploring knowledge, weaknesses or harmonious interactions between humans and the environment will make it easy for students to understand the environment or nature as they explore. Therefore, in applying the Problem Based Learning model it is necessary to insert the teaching of the Tri Hita Karana concept so that the interaction of learning at the time of applying the Problem Based Learning model can run well to obtain optimal learning outcomes.

The Tri Hita Karana oriented Problem Based Learning model directs students to find knowledge through solving a problem related to nature by having good interactions with God, teachers, friends, and the environment. So with the Tri Hita Karana oriented Problem Based Learning model students learn with a good mental or psychological state. This will make them focus in exploring finding meaningful knowledge. The expected advantages of the Tri Hita Karana oriented Problem Based Learning model are that students are active in exploring and constructing knowledge from the environment by applying scientific methods and promoting good characters so that the science learning outcomes obtained are more optimal than before. The purpose of this study was to determine the effect of the Tri Hita Karana-oriented Problem Based Learning model on the Learning Outcomes of Science in fifth grade students in Cluster III of Selemadeg District in the academic year 2019/2020.

\section{Methodology}

This study used an experimental research method. According to Kerlinger (in Setyosari, 2015) the experimental method is a study in which the researcher manipulates and controls one or more independent variables in observing control variables. The form of quasi-experimental design used in this study is a non-equivalent design. Similar research is often used in experiments that use classes that have already been formed and there is no randomization of individuals in determining the samples that are used as experimental and control groups. Thus, in this study no new classes were formed in the study.

The research design used in this study is a non-equivalent post-test only control group design, in the implementation of research designs with this type the experimental group was treated with a Tri Hita Karana oriented Problem Based Learning model and the control group was treated with a conventional model. Then the two groups both the experimental group and the control group were given a post-test to find out the differences in science learning outcomes between the experimental groups treated with the Tri Hita Karana oriented Problem Based Learning model and the control group treated with conventional learning models.

The populations in this study were all fifth grade students in Cluster III Selemadeg Subdistrict, amounting to 6 classes with a total of 159 students. While, the sample was taken by random sampling technique after population equalization. The results of taking the sample resulted in 2 classes as samples, namely the fifth grade students of SDN 3 Wanagiri totaling 28 students as the experimental class treated with the Tri Hita Karana oriented Problem Based Learning model and the fifth grade 
students of SDN 1 Pupuansawah totaling 28 students as the control class treated with conventional learning models.

The data in this study were collected with 30 objective test instruments developed based on 10 indicator items from the 7th grade $V$ theme question grid about "Events in Life". Before being used to retrieve data in the experimental and control groups, the objective test instruments were tested for content validity / expert first and the results showed 30 valid values. The test instrument was then tested on 60 students, then the score data obtained by the 60 students were analyzed for validity, reliability, distinguishing features, and the level of difficulty using Microsoft Excel. The results can be seen in table 1.

Table 1. Instrument Trial Data Analysis Results

\begin{tabular}{llcll}
\hline Category & Validity & Reliability & Distinguishinger & Difficulty level \\
\hline 30 & High & 9 questions are & 12 difficult questions \\
& Questions & very good & 16 moderate questions \\
& Valid & 13 good questions & 2 easy questions \\
& & $\begin{array}{l}\text { 8 questions is good } \\
\text { enough }\end{array}$ \\
& &
\end{tabular}

Based on table 01 above, it can be seen that the quality of the instrument is feasible to use for the post test in the experimental group and the control group to collect data on the learning outcomes of fifth grade science students.

After the science learning outcomes data was obtained from the post-test implementation, the data was then analyzed using descriptive statistics, which are calculating the mean (mean) and then consulted with the Benchmark Reference Assessment (PAP) to find out the category of science learning outcomes obtained by students both in the experimental group and control group as in table 2 below.

Table 2. Benchmark Reference Assessment Criteria (PAP)

\begin{tabular}{ll}
\hline Percentage of Mastery & Category \\
\hline $90-100$ & Very high \\
$80-89$ & High \\
$65-79$ & Is \\
$55-64$ & Low \\
$0-54$ & Very low \\
\hline
\end{tabular}

(Source: Agung, 2010)

The next stage of science learning outcomes data was tested with inferential statistics, namely the prerequisite test in the form of normality test with chi-square and homogeneity test with the F-test, after the prerequisite tests were met then continued with the hypothesis test using t-test conducted manually to find out the truth of the hypothesis of differences science learning outcomes between students in the experimental group and students in the control group who were treated differently.

\section{Finding and Discussion}

This research was conducted by giving different treatment between the experimental group and the control group. The experimental group was treated with a Tri Hita Karana oriented Problem Based Learning model and the control group was treated with a conventional learning model. Before giving treatment the teacher in charge of teaching in the experimental class was given training in applying the Tri Hita Karana oriented Problem Based Learning model for 2 weeks so that the teacher was ready to apply the Tri Hita Karana oriented Problem Based Learning model appropriately. Whereas the teacher in charge of teaching in the control group did not receive any teaching training because the model that will be applied to the control group is the conventional learning model that is used daily.

The treatment in each sample group was given seven times and at the time of the study students were completely unaware that they were being the subject of research. After the treatment had been completed given continued by giving a post test to find out the learning outcomes.

Science learning outcomes data in the experimental and control groups can be presented in the bar graph in Figure 1 below. 


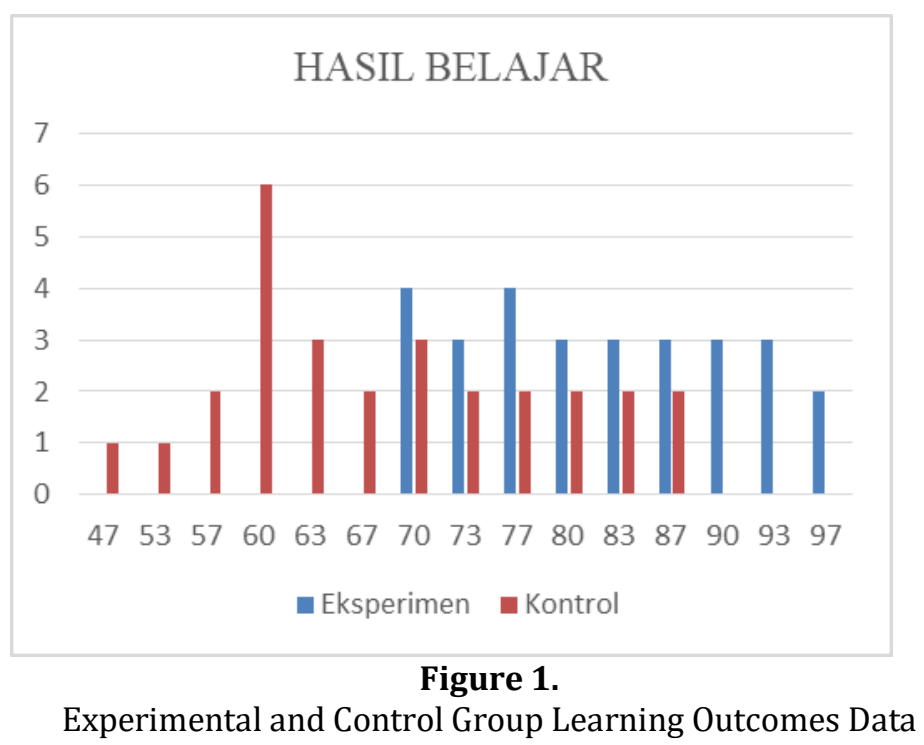

Based on the diagram above, it can be seen that students who score 70 or KKM standards are more attained by students in the experimental group, even students in the experimental group have no score less than 70 or KKM standards. So it shows that the Tri Hita Karana-oriented Problem Based Learning model that is applied to the experimental group has a better influence on the learning outcomes of Natural Sciences compared to conventional learning models that are applied to the control group.

Furthermore, the science learning outcomes data of the experimental group and control group students were analyzed by descriptive statistical tests in the form of the mean $(\overline{\mathrm{X}})$ and followed by prerequisite tests, namely the normality test with chi-square and the homogeneity test with the F-test presented in Table 3 below.

Table 3. Descriptive Statistical Analysis and Test Prerequisites for Science Learning Outcomes

\begin{tabular}{|c|c|c|c|c|c|c|c|}
\hline Descrip & ve statistics & \multicolumn{4}{|c|}{ Normality Test } & Hom & Test \\
\hline \multirow{2}{*}{\multicolumn{2}{|c|}{$\begin{array}{c}\text { Mean } \overline{\mathrm{X}} \\
\text { eriment }\end{array}$}} & \multicolumn{2}{|c|}{ Experiment } & \multicolumn{2}{|c|}{ Control } & \multicolumn{2}{|c|}{ Exsperiment \& Control } \\
\hline & & & $\mathbf{X}^{2}$ table & $\mathrm{X}^{2}$ count & $\mathbf{X}^{2}$ table & F-count & $F_{\text {table }}$ \\
\hline 82,14 & 68,11 & 5,82 & 7,82 & 3,93 & 7,82 & 1,52 & 1,90 \\
\hline \multicolumn{2}{|c|}{$\overline{\mathrm{X}}$ Experiment $>\overline{\mathrm{X}}$ Control } & \multicolumn{2}{|c|}{$\mathrm{X}^{2}$ count $<\mathrm{X}^{2}$ table } & \multicolumn{2}{|c|}{$\mathrm{X}^{2}$ count $<\mathrm{X}^{2}$ table } & \multicolumn{2}{|c|}{ F-count $<\mathrm{F}_{\text {table }}$} \\
\hline
\end{tabular}

Based on table 3 above, it can be seen that the average science learning outcomes of the experimental group that are taught using the Tri Hita Karana oriented Problem Based Learning model are higher than the control groups that are taught with conventional learning models. This means that the Tri Hita Karana-oriented Problem Based Learning model is more effective in improving science learning outcomes than conventional learning models. After analyzing the science learning outcomes with descriptive statistics, it was continued with the prerequisite test, namely the normality test and the homogeneity test. Through the normality test of science learning outcomes data with chi-square in the experimental group and the control group can be known in both groups X2 count $<\mathrm{X} 2$ table so that it can be said the learning outcomes data in the experimental group and the control group are normally distributed. Through the homogeneity test with the $\mathrm{F}$ test data the learning outcomes of the experimental group and the control group can be known F-count <Ftable so that it can be said the learning outcome data in the experimental group and the control group are homogeneous.

The data from the experimental group and the control group have met the prerequisite tests so that hypothesis testing can be done by t-test manually to find out the truth of the hypothesis that there are significant differences between the groups of students who are taught with the Tri Hita Karanaoriented Problem Based Learning model and and the group of students who are taught with conventional learning models. Recapitulation of t-test analysis of science learning outcomes can be seen in Table 4. 
Table 4. Recapitulation of Data Analysis of Science Learning Outcomes Using T-Test

\begin{tabular}{llllllrrr}
\hline No & Sample & $\mathrm{N}$ & $\mathrm{Dk}$ & $\overline{\mathrm{X}}$ & $\mathrm{S}^{2}$ & $\mathrm{~T}$-count & T-table & \multicolumn{2}{c}{ Status } \\
\hline 1 & Control Group & 28 & & 68,11 & 113,06 & & & \\
2 & Experiment & 28 & 54 & 82,14 & 74,57 & 5,42 & 1,67 & Ho rejected \\
& Group & & & & & & & \\
\hline
\end{tabular}

T-test analysis results obtained $\mathrm{T}$-count $=5.42$. This value is then compared with the T-table value with $\mathrm{dk}=28+28-2=54$ and a significance level of $5 \%$ so that the T-table value $=1.67$ is obtained. Because T-count $=5.42>$ T-table $(\alpha=0.05)=1.67$, H0 which states that there is no significant difference in science learning outcomes between the classes being studied with the Problem Based Learning model oriented Tri Hita Karana and the class which was taught with conventional learning models in the fifth grade elementary school in Cluster III Selemadeg Subdistrict, Tabanan Regency 2019/2020 Academic year was rejected and H1 stated that there were significant differences in science learning outcomes between the classes being studied with the Tri Hita Karana oriented Oriented Problem Based Learning model and the class which is taught with conventional learning models in class V elementary school in Cluster III Selemadeg District, Tabanan Regency 2019/2020 Academic year is accepted. This means that there are significant differences in science learning outcomes between groups of students who are taught with the Problem Based Learning model oriented Tri Hita Karana and groups of students who are taught with conventional learning models in fifth grade students in Elementary School Cluster III Selemadeg District in 2019/2020.

Significant differences indicate that the Tri Hita Karana-oriented Problem Based Learning model influences student learning outcomes in science. The effect of the Tri Hita Karana-oriented Problem Based Learning model on science learning outcomes can be seen from the differences in the results of descriptive statistical analysis between the two sample groups namely the science learning outcomes of the experimental group $\bar{X}=82.14$ which is higher than the average of the science learning outcomes of the control group $\overline{\mathrm{X}}=68.21$.

The Tri Hita Karana oriented Problem Based Learning model can improve science learning outcomes because the model can direct students to gain meaningful knowledge. In constructing knowledge, students are directed to solve a problem related to daily life with psychological conditions that are ready to learn. In applying the Problem Based Learning model students solve a problem by applying scientific methods and attitudes and implementing the teachings of the concept of Tri Hita Karana namely Parahyangan or a harmonious relationship with God that makes students always obey religious teachings in the learning process such as praying before doing the learning process that creates psychological conditions they are more ready to study. Harmonious or harmonious relationship between students and students and students with teachers who make the exchange of ideas or information can run well and make students always apply scientific attitude honest, open, accept the opinions of others / think politely, can cooperate, be responsible, resilient and persistent . The weakening or harmonious relationship of students with their environment makes students always understand their environment well, such as knowing the causes and consequences of a treatment given to the environment so that knowledge can be constructed well on the cognitive structure of students. Through the application of the concept of Tri Hita Karana the character of students during learning can be directed to be better so as to minimize the occurrence of an obstacle in learning. This i: $\quad 234$ ed by the results of research conducted by Sanjaya (2019) which states that Tri Hita Karana c........... ve student character during the learning process.

The Tri Hita Karana oriented Problem Based Learning model has a learning syntax as learning with the usual Problem Based Learning model, namely: (1) student orientation to the problem (2) organizing students to learn (3) guiding individual and group experiences (4) developing and presenting the work, and (5) analysis and evaluation of the problem solving process. The support of the three concepts of Tri Hita Karana on the application of the syntax of the Problem Based Learning model directs students to interact well during learning so that the learning process can run more smoothly and conducive. The application of the Tri Hita Karana oriented Problem Based Learning model makes students solve problems by directly exploring the environment with their friends accompanied by good interactions so that what students get from the environment can be understood and interpreted.

Stage of student orientation to the problem, students are directed to focus their thoughts on the learning process by praying first and continuing with the introduction of problems relating to humans (Pawongan) and nature (Palemahan). The role of the teacher at this stage is to ensure students are 
truly focused on the learning process and make students aware that the problems presented in learning will relate to students' daily lives. The relationship of this step to the learning outcomes of science lies in the focus of students' minds on the learning process or the psychological condition of students ready to learn so that learning material is easily understood by students.

The stage of organizing students to learn, at this stage students are directed to discuss with their study groups about the steps and tasks performed in solving problems. The role of the teacher at this stage is to direct students to discuss well (Pawongan) and think critically and apply scientific methods during learning. The relationship of this stage to the learning outcomes of science lies in the ability to collaborate students with their study partners in finding or exchanging ideas in solving a problem so that ideas obtained through the collaborative process can enrich students' knowledge that positively influences student learning outcomes. This is in line with Vigotsky's learning theory, which is the social aspect that influences cognitive intelligence (Rusman, 2012).

The phase of guiding individual and group experiences, at this stage students are directed to interact with the environment (Palemahan) in gathering information and collaborating during experiments (Pawongan). The teacher's role at this stage is to encourage students to be skilled in collaborating with their peers and to be careful in carrying out experiments. The relationship of this stage to the learning outcomes of science lies in the ability of students to collaborate and explore the environment. Concepts obtained from the environment by collaborating with friends make the concepts obtained by students more understood and meaningful so as to provide an increase in learning outcomes. This is in line with Jerome S. Bruner's learning theory, that is, the knowledge gained independently in solving a problem will become meaningful knowledge for students (Rusman, 2012).

The stage of developing and presenting the work, in this stage students are directed to work together (Pawongan) with their groups to make a work or report that can explain how they solve problems. The role of the teacher at this stage is to make all students able to conclude solving the problems they have done with their respective creativity. The relationship of this stage with learning outcomes lies in the ability of students to conclude something they have done into a meaningful concept so that the concept is easy for students to remember that will affect the learning outcomes of Natural Sciences.

The analysis and evaluation stages of the problem solving process, students in this case are encouraged to dare to present to their friends (Pawongan) about how they solve problems and conclusions obtained. The teacher's role at this stage is to encourage students to speak up to share information with their friends (Pawongan). The relationship of this step to learning outcomes lies in the ability of students to communicate about what they have gotten from the learning process or it can be said to be a process of reflection so that at this stage it can be known the incorrect or correct concepts obtained by students. The wrong concept must be directed by the teacher to be the correct concept so that it will cause the science learning outcomes to increase. This is in line with David Ausabel's learning theory, namely that the synchronization of new information and old information will become a more confusing information structure in students' memories (Rusman, 2012).

The application of the syntax of the Tri Hita Karana-oriented Problem Based Learning model above has a positive influence on improving student learning outcomes or abilities after going through the learning process within a certain period of time. That is because learning outcomes are strongly influenced by the learning model and teaching atmosphere. The Problem Based Learning model corresponds to science learning which requires students to learn through exploration by applying scientific methods and attitudes to the environment to develop scientific reasoning. So that it makes the knowledge or concepts obtained by students more understood and interpreted or in other words the Problem Based Learning model is a suitable model applied to science learning to improve learning outcomes. This is consistent with the results of research conducted by Shofiyah (2018) which states the Problem Based Learning model is able to develop students' scientific reasoning that can improve the learning outcomes of Natural Sciences.

The application of the Tri Hita Karana concept in learning makes the teaching atmosphere more conducive due to the development of harmonious learning interactions between students and students, students and teachers, and students with the environment caused by the formation of good character during learning. That makes the Tri Hita Karana oriented Problem Based Learning model can improve the science learning outcomes.

The presentation shows that the Tri Hita Karana-oriented Problem Based Learning model is student-centered and emphasizes good interactions during learning. This is different from conventional learning models that are applied in control classes that are more teacher-centered. Learning that is too centered on the teacher makes students lack of understanding and understanding of learning. Student interaction is also not well directed during the learning process which makes them 
not respect the teacher who teaches in front of the class. This makes the learning outcomes of science in the control class lower than the experimental group learned with the Tri Hita Karana oriented Problem Based Learning model. The results of this study are supported by research conducted by Nurqomariah (2015) which states that the learning outcomes of Natural Sciences in the group of students who are taught with the Problem Based Learning model are higher than the groups of students who are taught with conventional learning models.

The results of this study support similar research conducted earlier by Saputra (2018) who concluded that there were significant differences in science learning outcomes between groups of students who were taught with the Tri Hita Karana oriented Problem Based Learning model and groups of students who were taught with conventional models. That is because in this study the experimental group was given the same treatment as the previous research, namely problem solving by putting forward the value of the concept of Tri Hita Karana (Parahyangan, Pawongan, and Palemahan).

The novelty of this study compared to previous studies conducted by Saputra (2018), namely the average learning outcomes obtained in the experimental class. In previous studies, the average science learning outcomes obtained by the experimental group that were taught with the Tri Hita Karana oriented Problem Based Learning model were $\bar{X}=77.68$, which when consulted with Benchmark Reference (PAP) was in the medium category while the average learning outcomes The science obtained by the experimental group that was taught with the Tri Hita Karana-oriented Problem Based Learning model in this research was $\overline{\mathrm{X}}=82.14$ which when consulted with Benchmark Reference Assessment (PAP) was in the high category. So that the results obtained in this study are more optimal than previous studies.

\section{Summary and Conclusion}

Based on the data analysis, it can be concluded that the application of the Tri Hita Karana oriented Problem Based Learning model has an effect on the learning outcomes of the fifth grade students in Elementary School in Selemadeg District, 2019/2020 Academic Year. Based on this research, the suggestions that can be delivered are as follows. Teachers should teach learning that there is a science content to direct students to interact with the environment so that the knowledge obtained can be more accepted by students who still cannot think abstractly, therefore the Tri Hita Karana oriented Problem Based Learning model can be a learning model that helps in directing students to gain knowledge through direct interaction with the environment. The principal should be able to manage the availability of funds to provide learning media that can facilitate students to learn and time management so students can take knowledge independently by interacting with the environment so that knowledge is more meaningful. To other researchers, it should be possible to examine the improvement of science learning outcomes using local local wisdom so that noble cultural values are not eroded by the progress of the times.

\section{References}

Agung, A. A. G. (2010). Evaluasi Pendidikan. Singaraja: Undiksha.

Agung, A. A. G. (2010). Metodologi Penelitian Pendidikan, Suatu Pengantar. (FIP Undiksha Singaraja, Ed.). Singaraja.

Amir, \& Haling, A. (2018). The Effect of Scientific Approach at Natural Science Learning on Elementary Students' Learning Outcome 227(Icamr 2018). Advances in Social Natural Science, Education and Humanities Research (ASSEHR), 13-15. https://doi.org/https://doi.org/10.2991/icamr18.2019.4

Ardaya, D. A. (2016). Penerapan Pendekatan Saintifik Untuk Kelas V Sekolah Dasar. Jurnal Pendidikan Guru Sekolah Dasar, I(I), 72-83.

Ardiansyah. (2017). Pengaruh Model Pembelajaran Problem Solving Terhadap Hasil Belajar IPA Siswa SD. MIMBAR PGSD Undiksha, 5(2), 1-11.

Ariadi, I. P. (2014). Pengaruh Model Group Investigation (GI) Terhadap Hasil Belajar IPA Siswa. EJournal MIMBAR PGSD Universitas Pendidikan Ganesha, 2(1), 1-10. https://doi.org/https:// doi.org/10.1145/302979.303168

Fauziyah. (2017). Pengaruh Model Pembelajaran Probing-Promting Terhadap Hasil Belajar Pada Tema 8 (Ekosistem) Siswa Kelas V SDN Wiyung I Surabaya. Jurnal Pendidikan Guru Sekolah Dasar, 
5(5), 533-542.

Mahpudin. (2018). Peningkatan Hasil Belajar Ipa Melalui Metode Eksperimen Pada Siswa Kelas V Sekolah Dasar. Jurnal Cakrawala Pendas, 4(2), 1. https://doi.org/https://doi.org/ 10.31949/jcp.v4i2.1029

Mandra, I. W., \& Dhammananda, D. (2020). Implementation Of Tri Hita Karana Teaching To Form Students Characters Quality. Jurnal Penjaminan Mutu, 6(1), 60. https://doi.org/https:// doi.org/10.25078/jpm.v6i1.1300

Muakhirin, B. (2014). Peningkatan Hasil Belajar Ipa Melalui Pendekatan Pembelajaran Inkuiri Pada Siswa Sd. Jurnal Ilmiah Guru Caraka Olah Pikir Edukatif, 0(1).

Nurqomariah. (2015). Pengaruh Model Problem Based Learning Dengan Metode Eksperimen Terhadap Hasil Belajar IPA Fisika Siswa Kelas Vii. Jurnal Pendidikan Fisika Dan Teknologi, 1(3), 173-178.

Priani. (2018). Pengaruh Model Problem Based Learning (PBL) Berbantuan Media Gambar Terhadap Hasil Belajar IPA Siswa Kelas V Gugus III Kuta Utara Tahun Pelajaran 2017/2018. Mimbar PGSD, 6(1), 8-14.

Putra, I. W. G. Y. D. (2020). Pengaruh Sistem Pengendalian Internal, Budaya Tri Hita Karana Pada Kinerja Pemerintah. Jurnal Lingkungan \& Pembangunan, 4(1).

Rusman. (2012). Model-model Pembelajaran. PT Raja Grafindo Persada.

Sanjaya. (2019). Utilization of Civic KVS-SAW Evaluation Model in Determining the Effectiveness of Tri Hita Karana in Character Education for Students on Elementary School of Bali Aga. Journal of Engineering and Applied Natural Sciences, 14(8), 2572-2581.

Saputra. (2018). Pengaruh Model Pembelajaran Problem Based Learning Berorientasi Tri Hita Karana Terhadap Hasil Belajar IPA Siswa Kelas V. Jurnal Pendidikan Multikultural Indonesia, 1(2), 51 61.

Setyosari. (2015). Metode Penelitian Pendidikan \& Pengembangan. Prenadamedia Group.

Shofiyah. (2018). Model Problem Based Learning (PBL) Dalam Melatih Scientific Reasoning Siswa. Jurnal Penelitian Pendidikan IPA, 3(1), 33. https://doi.org/https://doi.org/10.26740/ jppipa.v3n1.p33-38

Sohibun. (2014). Penerapan Strategi Belajar Dengar Lihat Kerjakan (DELIKAN) Berbasis Laboratorium Mini Terhadap Keterampilan Proses. Jurnal Imiah, 3(1).

Soviawati, E. (2011). Pendekatan Matematika Realistik (PMR) untuk Meningkatkan Kemampuan Berfikir Siswa di Tingkat Sekolah Dasar. Jurnal Penelitian Pendidikan, Edisi Khus(2), 154-163.

Suci, I. G. S. (2018). Higher Education Management Base on Tri Hita Karana: Case Study Hindu Higher Education Instution. International Journal of Mechanical Engineering and Technology, 9(8), 4658.

Sulthon. (2016). Pembelajaran Ipa Yang Efektif Dan Menyenangkan Bagi Siswa Madrasah Ibtidaiyah (Mi). Elementary, 4(1), 38-54.

Wayan Weda Gustana Putra, I., Putu Parmiti, D., \& Wayan Suwatra, I. I. (2016). Pengaruh Model Pembelajaran Savi Bermuatan Tri Hita Karana Terhadap Hasil Belajar Ipa Siswa Kelas IV. EJournal PGSD Universitas Pendidikan Ganesha, 4(1).

Widura. (2018). Pengaruh Model Core Berbantuan Media Visual Terhadap Hasil Belajar IPA. Jurnal for Lesson and Learning Studies, 1(3), 258-26. 